\title{
Karakterisasi Sumber Daya Genetik Itik Bayang Berdasarkan Marka Mikrosatelit Lokus CMO211 dan Lokus AY295
}

\author{
Genetic Resources Characterisation of Bayang Duck Based on Microsatelite Marker Of \\ CMO211 and AY295 loci
}

\author{
Rusfidra $^{1)}$,Y. Heryandi ${ }^{1)}$, Jamsari ${ }^{2)}$, dan E. Y. Rahman ${ }^{3)}$ \\ ${ }^{1)}$ Program Studi Peternakan, Fakultas Peternakan Universitas Andalas, Padang \\ ${ }^{2)}$ Laboratorium Bioteknologi, Fakultas Pertanian Universitas Andalas, Padang \\ ${ }^{3)}$ Program Pascasarjana Universitas Andalas, Padang \\ Kampus Limau Manis, Padang, 25163 \\ Corresponding Author: rusfidra@faterna.unand.ac.id
}

\begin{abstract}
ABSTRAK
Itik Bayang merupakan plasma nutfah Sumatera Barat yang berperan penting sebagai penghasil daging dan telur. Marka mikrosatelit banyak digunakan sebagai penciri genetik karena keberadaannya berlimpah, bersifat kodominan dan polimorfik. Tujuan penelitian ini adalah untuk mengidentifikasi keragaman genetik itik Bayang berdasarkan marka mikrosatelit lokus CMO211 dan AY295. Material DNA yang digunakan adalah sampel darah dari 24 ekor itik Bayang di Kecamatan Bayang dan Kecamatan Lengayang Kabupaten Pesisir Selatan. Hasil isolasi DNA dari 24 sampel darah itik Bayang dapat dideteksi oleh gel elektroforesis. Lokus CMO211 menampilkan 2 alel, yakni alel A dan alel B dengan panjang alel 150-200 bp. Frekuensi kedua alel adalah alel A $(87,5 \%)$ dan alel B (12,5\%). Lokus AY295 menampilkan 7 alel, yaitu alel A (214 bp), alel B (245 bp), alel C (273 bp), alel D (300 bp), alel E (324 bp), alel F (359 bp) dan alel G (454 bp). Frekuensi alel berturut-turut adalah alel B (24\%), alel A (16\%), alel C (16\%), alel D (16\%), alel E (12\%), alel F (12\%) dan alel G (4\%). Hasil amplifikasi menunjukkan lokus CMO211 dan AY295 bersifat polimorfik pada itik Bayang.
\end{abstract}

Kata kunci : itik Bayang, mikrosatelit, lokus CMO211, lokus AY295

\begin{abstract}
Bayang duck is poultry genetic resources in West Sumatera Province and set by Indonesian Agricultural Ministry as national livestock breeds in Indonesia. Microsatellite markers are widely used as a genetic identifier because of their abundant existence, codominant and polymorphic nature. The purpose of this study was to determine the genetic diversity of Bayang ducks based on two microsatellite loci which include CMO211 and AY295. The DNA substances used in the study were blood samples from 24 ducks of Bayang duck in Bayang and Lengayang Districts in Pesisir Selatan Regency. DNA isolated from blood samples of 24 Bayang duck could be detected by gel electrophoresis. CMO211 exhibited 2 alleles, allele A and allele B with allele size of 150 $200 \mathrm{bp}$, and frequency of allele A (87,5\%) and allele B (12,5\%). AY295 showed 7 alleles consisted allele A (214 bp), allele B (245 bp), allele C (273 bp), allele D (300 bp), allele E (324 bp), allele F (359 bp) and allele G (454 bp) with frequency allele B (24\%), allele A (16\%), allele C (16\%), allele D (16\%), allele E (12\%), allele F $(12 \%)$ and allele $\mathrm{G}(4 \%)$. The results showed that CMO211 and AY295 were polymorphic of Bayang duck.
\end{abstract}

Key words: microsatellite marker, Bayang duck, CMO211, AY295

\section{PENDAHULUAN}

Itik Bayang merupakan sumber daya genetik ternak itik di Provinsi Sumatera Barat yang berperan penting sebagai penghasil daging dan telur. Rusfidra dan Heryandi (2010); Rusfidra et. al. (2012); Kusnadi dan Rahim (2009) menyatakan bahwa itik Bayang merupakan itik Lokal yang dipelihara petani/peternak di Kabupaten Pesisir Selatan dan sangat potensial dikembangkan sebagai penghasil daging dan telur. Penampilan itik Bayang dapat dilihat pada Gambar 1. 


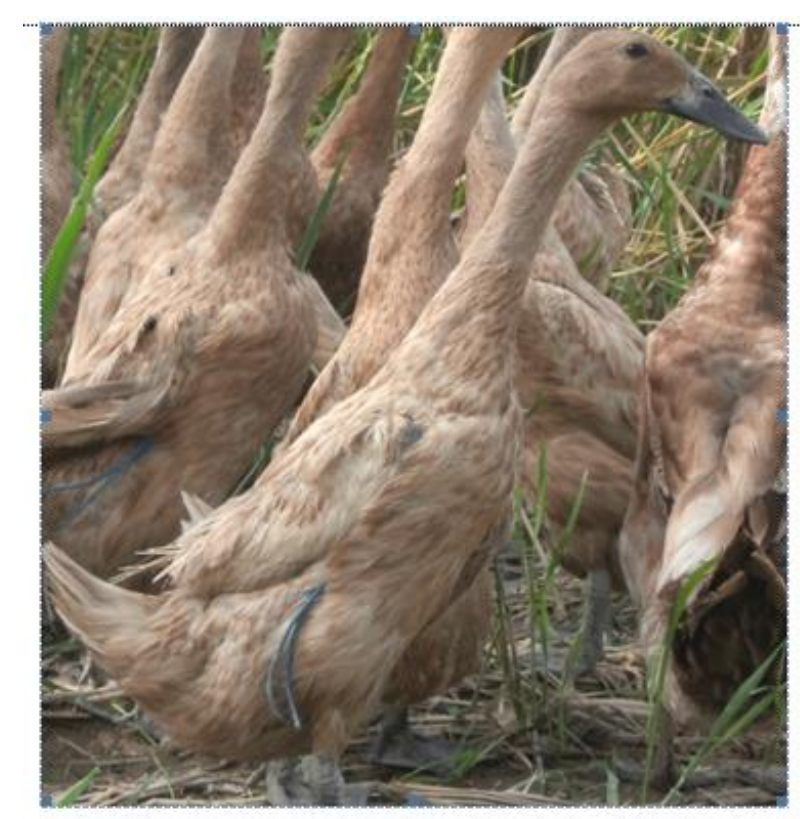

Gambar 1a. Itik Bayang Betina

Selain marka morfologis, keragaman genetik dapat dipelajari dengan melihat variasi alel DNA berdasarkan penciri genetik molekuler. Keragaman genetik sangat diperlukan dalam upaya pemuliaan ternak, karena dengan diketahuinya keragaman genetik ternak dimungkinkan untuk membentuk bangsa ternak baru melalui seleksi dan sistem perkawinan. Marka molekuler dapat menyediakan kriteria kuantifikasi untuk mempelajari keragaman genetik, baik di dalam populasi, maupun antar populasi (Tixier-Boichard et.al. 2009).

Sampai kini karakterisasi marka molekuler itik Bayang sebagai plasma nutfah belum banyak dilakukan. Salah satu pendekatan yang dapat dilakukan adalah mengetahui keragaman genetik itik Bayang berbasis marka mikrosatelit. Materi genetik (DNA) yang ditemukan pada

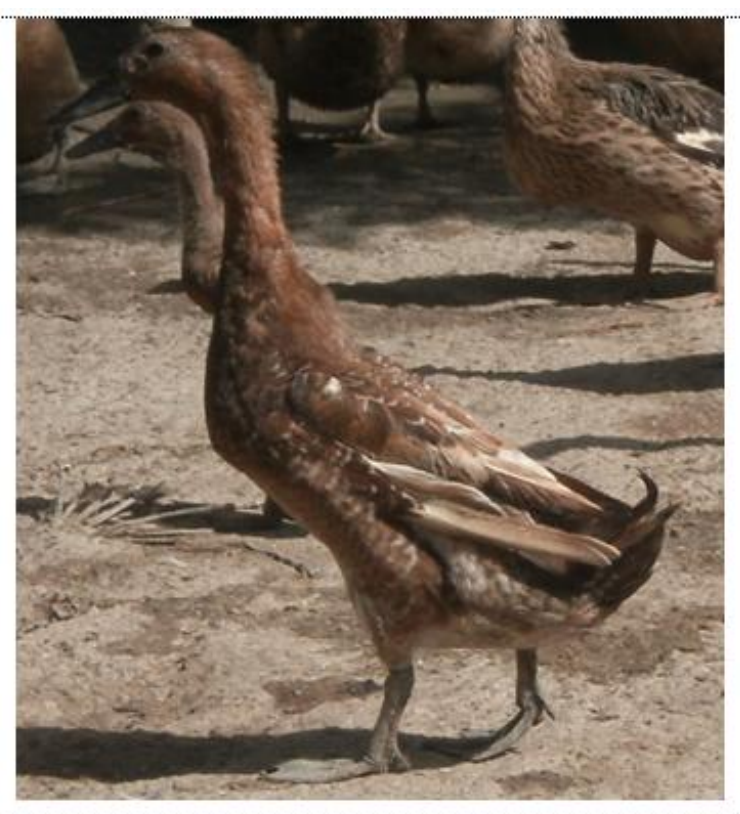

Gambar 1b. Itik Bayang Jantan

semua mikroorganisme sebagian besar belum diketahui fungsinya, hanya sekitar $10 \%$ dari total DNA yang diketahui berfungsi sebagai penyandi genetik, sedangkan $90 \%$ adalah DNA bukan gen seperti mikrosatelit (Moxon dan Willis, 1999). DNA bukan gen yang berulang secara berurutan disebut mikrosatelit. Mikrosatelit atau juga dikenal Short Tandem Repeats (STRs) merupakan untaian basa nukleotida 1-6 pasang basa yang berulang dan tersebar di dalam genom (Clementino et. al. 2010).

Mikrosatelit merupakan penanda genetik yang sering digunakan untuk mempelajari pautan (linkage), pemetaan, analisis populasi, sistem perkawinan dan struktur populasi (Silva et.al., 1999). Mikrosatelit banyak digunakan sebagai penciri genetik karena keberadaannya berlimpah, bersifat kodominan dan 
polimorfik (Bennet, 2000). Mikrosatelit juga dapat digunakan untuk keperluan identifikasi individu, keanekaragaman dan struktur populasi, dan mempelajari evolusi spesies berkerabat (Clisson et.al., 2000). Ciampolini et.al. (1995) menyatakan bahwa DNA mikrosatelit banyak digunakan sebagai penanda molekuler untuk mendukung aktifitas pemuliaan ternak seperti kegiatan identifikasi ternak, penetapan asal-usul keturunan dan penggalian sumber-sumber genetik.

Variasi alel mikrosatelit dapat dihitung melalui pemisahan produk PCR menggunakan elektroforesis. Dengan mengidentifikasi pita yang muncul setelah elektroforesis (satu pita untuk homozigot dan dua pita atau lebih untuk heterozigot) maka genotip suatu individu dapat ditentukan dan frekuensi alel dalam suatu populasi dapat dihitung (Muladno, 2000). Mikrosatelit dapat digunakan untuk mengidentifikasi asal-usul individu dari suatu populasi (Edwards et. al., 2000).

Tujuan penelitian ini adalah untuk mengidentifikasi keragaman genetik itik Bayang berdasarkan marka mikrosatelit lokus CMO211 dan lokus AY295. Hasil penelitian diharapkan dapat digunakan sebagai dasar program pemuliaan itik Bayang di Sumatera Barat.

MATERI DAN METODE

\section{Ternak dan Pengambilan Sampel Darah}

Material DNA yang digunakan untuk marka mikrosatelit adalah sampel darah 12 ekor itik Bayang yang dipelihara peternak di Kecamatan Bayang dan 12 ekor itik Bayang di Kecamatan Lengayang, Kabupaten Pesisir Selatan, Sumatera Barat. Darah diambil dengan mengunakan jarum suntik 0,5 ml. Sampel darah diambil melalui vena akselaris pada bagian sayap sebanyak 0,3 ml, kemudiaan dimasukkan ke dalam tabung venojeck dan dikocok membentuk angka 8 dan disimpan dalam lemari es untuk mencegah pembekuan darah.

\section{Isolasi dan Purifikasi DNA}

Isolasi DNA dilakukan mengunakan metoda Sambrook et. al., (1989) dengan modifikasi dengan mengunakan purifikasi DNA kit produksi Promega. Isolasi DNA diawali dengan pengambilan $100 \quad \mu l \quad$ sampel darah dicampur dengan $300 \mu \mathrm{l}$ larutan sel lysis dan $8 \mu$ l proteinase $\mathrm{K}$ dalam tabung sentrifus steril ukuran 1,5 ml, dengan cara membolak-balik tabung sebanyak 5-6 kali. Larutan yang telah tercampur diinkubasi pada suhu $65^{\circ} \mathrm{C}$ selama 1 jam. Kemudian lakukan sentrifus dengan kecepatan 15.000 rpm selama 1 menit. Selanjutnya supernatan dibuang dan peletnya ditinggalkan. Proses isolasi diulangi sebanyak 3 kali. Pelet yang tersisa divortex 
sampai larut. Kemudiaan tambahkan 300 $\mu 1$ larutan nuclei lysis, kemudian dipipet cairan up-down sampai larutan bersifat viscous. Kemudian tambahkan protein precipitation sebanyak $200 \mu \mathrm{l}$ dan akan terbentuk endapan yang berwarna keruh. Selanjutnya larutan tersebut disentrifus dengan kecepatan 15.000 rpm selama 3 menit, sehingga terbentuk dua bagian, yakni pellet dan supernatan. Supernatan diambil dan ditransfer ke dalam tabung sentrifus baru yang steril (ukuran 1,5 ml) dan ditambah dengan isopropanol sebanyak $300 \mu 1$.

Supernatan yang telah dicampur tersebut disentrifus dengan kecepatan $15.000 \mathrm{rpm}$ selama 1 menit. Supernatant dibuang dan pellet dicuci dengan etanol $70 \%$ dingin sebanyak $500 \mu 1$. Pellet disentrifus dengan keepatan 10.000 rpm selama 5 menit. Etanol lalu dibuang dengan pipet, kemudiaan tabung dibalik dan dikeringkan di atas tisu pada suhu ruang selama 10-15 menit. Pellet yang telah dikeringkan ditambah dengan larutan DNA re-hydrasi $50-100 \mu \mathrm{l}$, kemudian tabung di-typing hingga pellet menjadi larut. Hasil isolasi tersebut diuji dengan menggunakan elektroforesis dengan campuran $4 \mu \mathrm{l}$ 1xTE, $1 \mu \mathrm{l}$ BPB, $2 \mu \mathrm{l}$ DNA dan $2 \mu 1 \quad \lambda$ - DNA ladder dengan menggunakan $1 \%$ agarose pada tegangan 100 volt selama 60 menit.

\section{Amplifikasi DNA Mikrosatelit dengan \\ Polymerase Chain Reaction (PCR)}

Reaksi PCR dilakukan menurut metode Sambrook et.al. (1989). Komposisi larutan untuk runing PCR terdiri dari Go

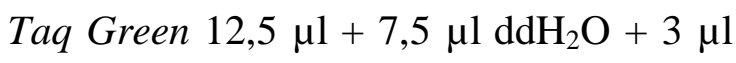
DNA sampel $+2 \mu 1$ primer $F$ dan $\mathrm{R}$. Primer yang digunakan dalam penelitian ini menggunakan primer yang yang telah dilaporkan Su et.al. (2007) (Tabel 1). Suhu annealing disesuaikan dengan suhu annealing masing-masing primer, yakni primer $\mathrm{CMO} 211 \quad\left(66{ }^{0} \mathrm{C}\right)$ dan primer AY295 $\left(55^{0} \mathrm{C}\right)$. Proses amplifikasi DNA berlangsung selama 2 jam 20 menit. DNA hasil amplifikasi lalu dielektroforesis bersama $1 \mathrm{~kb}$ DNA ladder dengan menggunakan $1,5 \%$ agarose pada tegangan 100 Volt selama 90 menit. Hasil elektroforesis diamati dengan $U V$ transiluminator. Pola pita DNA dipotret dengan unit gel dokumentasi.

Tabel 1. Primer yang digunakan pada itik Bayang.

\begin{tabular}{c|l|c|c|c}
\hline \multirow{2}{*}{ Lokus } & \multicolumn{1}{|c|}{ Sekuen primer } & $\begin{array}{c}\text { Suhu } \\
\text { Annealing } \\
\left({ }^{\circ} \mathrm{C}\right)\end{array}$ & $\begin{array}{c}\text { Ukuran } \\
\text { Alel }(\mathrm{bp})\end{array}$ & Referensi \\
\hline AY295 & $\begin{array}{l}\text { GGCTTCTGTGCTCCTCAGAT } \\
\text { GGACAAGTGGCATGTGTCAT }\end{array}$ & 66 & $253-403$ & Su et. al. (2007) \\
\hline \multirow{2}{*}{ CMO211 } & $\begin{array}{l}\text { GGATGTTGCCCCACATATT } \\
\text { TTGCCTTGTTTATGAGCCATT }\end{array}$ & 55 & $221-283$ & Su et. al. (2007) \\
\hline
\end{tabular}




\section{Penentuan Posisi Pita DNA Mikrosatelit}

Jika terdapat dua pita atau lebih maka sampel tersebut bersifat heterozigot dan jika terdapat satu pita maka bersifat homozigot. Untuk memudahkan skoring pita yang paling bawah diberi sandi A dan selanjutnya $\mathrm{B}, \mathrm{C}$, dan seterusnya sampai pita paling atas. Semua pita yang memiliki laju sama merupakan alel yang homolog (Nei, 1987).

\section{Analisis Data}

\section{Frekuensi Alel}

Frekuensi alel lokus CMO211 dan AY295 dihitung menurut Nei dan Kumar (2000):

$$
\begin{aligned}
& \qquad \mathbf{x}_{\mathbf{i}}=\left(\mathbf{2} \mathbf{n}_{\mathrm{ij}}+\boldsymbol{\Sigma} \mathbf{n}_{\mathrm{ij}}\right) /(\mathbf{2 N}) \\
& \text { Keterangan }: \mathrm{j} \neq 1 \\
& \mathrm{x}_{\mathrm{i}}=\text { frekuensi alel ke-i } \\
& \mathrm{n}_{\mathrm{ij}} \quad=\text { jumlah individu untuk } \\
& \text { genotip }_{\mathrm{ij}} \\
& \mathrm{N}=\text { jumlah sampel }
\end{aligned}
$$

\section{Frekuensi Genotipe}

Frekuensi genotipe ditentukan dengan cara membagi jumlah sampel itik Bayang yang memiliki genotipe tertentu dengan seluruh jumlah itik Bayang yang diamati dan dihitung menurut Nei dan Kumar (2000):

$$
\mathbf{x}_{\mathbf{i}}=\boldsymbol{\Sigma} \mathbf{n}_{\mathbf{i}} / \mathbf{N}
$$

Keterangan :

$x_{i}=$ frekuensi genotipe ke- $i$

$\mathrm{n}_{\mathrm{i}}=$ jumlah individu bergenotipe-i

$$
\mathrm{N}=\text { jumlah individu sampel }
$$

\section{HASIL DAN PEMBAHASAN}

\section{a. Isolasi DNA Genom dan Reaksi Amplifikasi PCR}

Hasil isolasi DNA dari 24 sampel darah itik Bayang yang terdeteksi oleh gel elektroforesis yakni 12 sampel itik dari Kecamatan Bayang dan 12 sampel itik dari Kecamatan Lengayang. Konsentrasi DNA yang diperoleh berkisar $200-400 \mathrm{ng}$.

\section{b. Amplifikasi DNA Mikrosatelit}

Amplifikasi DNA mikrosatelit pada itik Bayang dianalisis dengan menggunakan dua lokus, yaitu: CMO211 dan AY295 (Su et. al., 2007). Amplifikasi PCR pada kedua lokus dapat mengamplifikasi 24 sampel itik Bayang. Alel ditentukan oleh variasi pita DNA yang muncul pada gel agarose. Perbedaan yang muncul dianggap sebagai alel berbeda. Pola elektroforesis lokus CMO211 dan AY295 dapat dilihat pada Gambar 2 dan 3. 


\section{Lokus CMO211}

Lokus CMO211 menghasilkan 2 alel, yakni alel A dan alel B dengan panjang alel $150-200$ bp. Frekuensi alel berturut-turut adalah alel A sebesar $87,5 \%$ dan alel B sebesar 12,5\%. Jumlah dan ukuran alel pada CMO211 dapat dilihat pada Gambar 2. Jumlah dan ukuran alel pada itik Bayang lebih kecil dibandingkan dengan jumlah dan ukuran alel itik Lokal Cina, Tegal, Magelang dan Alabio. Su et. al. (2007) melaporkan bahwa jumlah alel pada itik Lokal Cina pada lokus CMO211 sebesar 14 alel, dengan ukuran alel 221 283 bp. Ismoyowati dan Purwantini (2009) melaporkan bahwa jumlah alel itik Tegal, Magelang dan Alabio adalah 5-7 alel dengan panjang alel $80-760 \mathrm{bp}$.

Gambar 2. Pola pita lokus CMO211

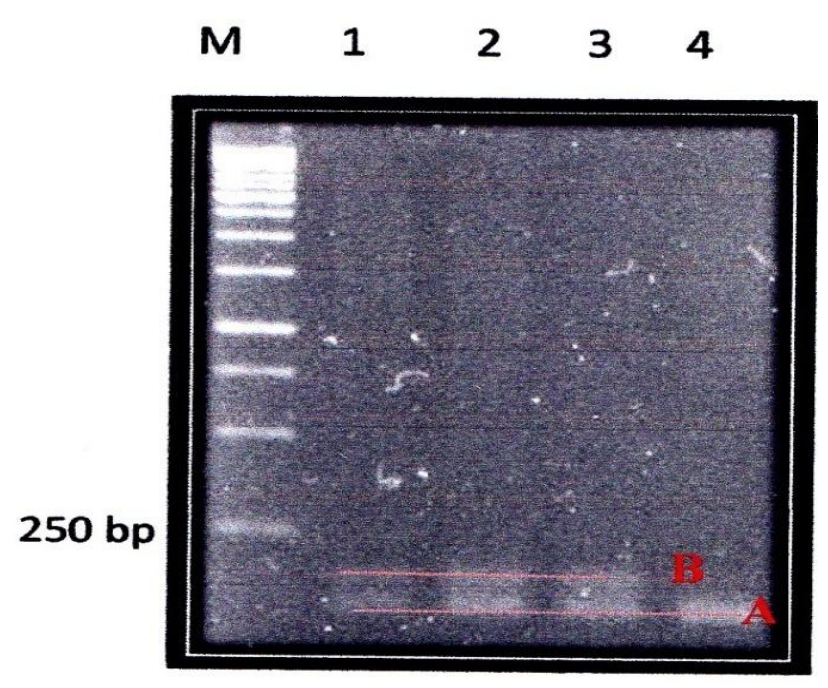

AB AB AB AA

Perbedaan ukuran dan jumlah alel yang dihasilkan pada lokus CMO211 antara itik lokal Cina, itik Tegal, Magelang dan Alabio dengan itik Bayang menunjukkan bahwa itik Bayang memiliki tingkat keragaman genetik relatif lebih rendah dibandingkan dengan itik lokal Cina, Tegal, Magelang dan Alabio.

\section{Lokus AY295}

Hasil penelitian menunjukkan bahwa lokus AY295 menghasilkan 7 alel, yaitu alel A (214 bp), alel B (245 bp), alel C (273 bp), alel D (300 bp), alel E (324 bp), alel F (359 bp) dan alel G (454 bp). Urutan frekuensi alel dari yang tertinggi sampai yang terendah adalah alel B (24\%), alel A (16\%), alel C (16\%), alel E (12\%), alel F (12\%) dan alel G (4\%). Jumlah dan ukuran alel pada lokus AY295 dapat dilihat pada Gambar 3. 


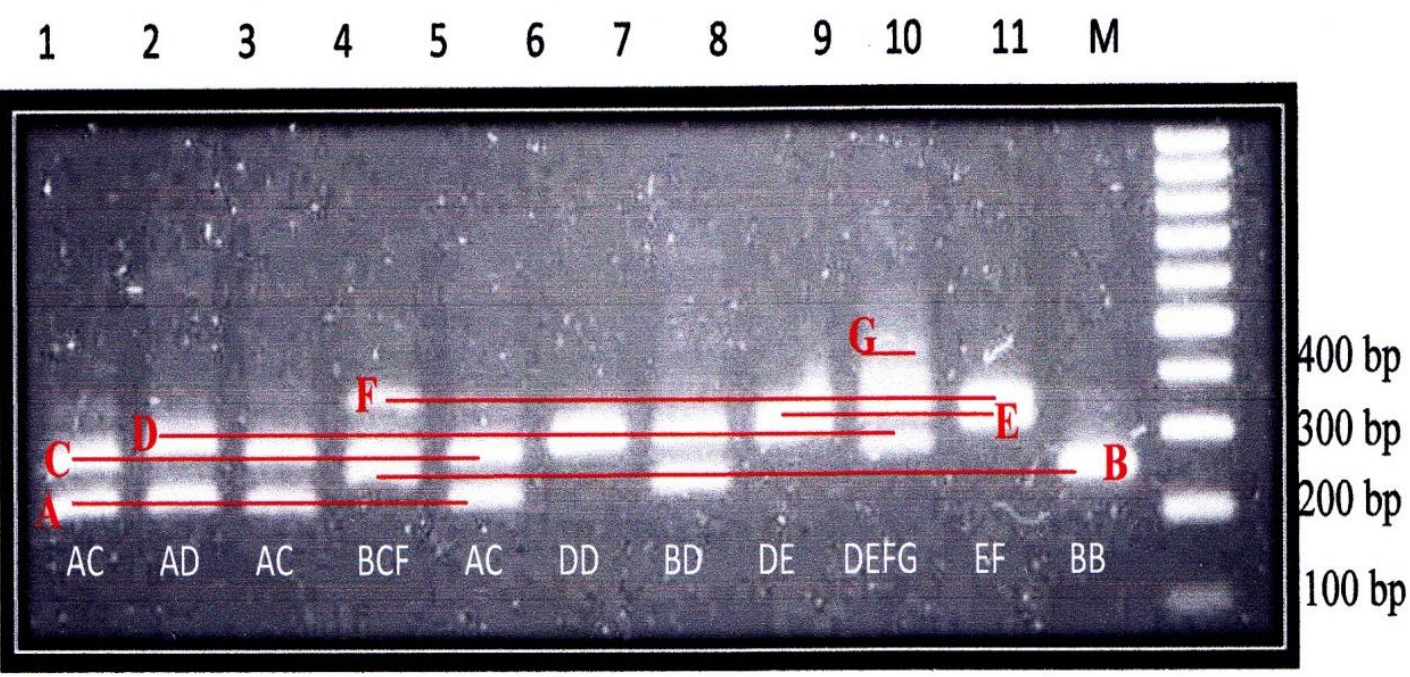

Gambar 3. Pola pita lokus AY295

Jumlah dan ukuran alel itik Bayang

lokus AY295 lebih kecil dibandingkan dengan jumlah dan ukuran alel lokus AY295 pada itik lokal Cina sebagaimana dilaporkan $\mathrm{Su}$ et. al., (2007). Jumlah alel pada itik lokal China lokus AY295 sebanyak 12 alel, dengan ukuran alel berkisar antara 253 - 403 bp. Perbedaan ukuran dan jumlah alel yang dihasilkan pada lokus AY295 menunjukkan bahwa itik Bayang memiliki tingkat keragaman genetik yang relatif rendah, karena menurunnya jumlah alel pada lokus yang berbeda akan menurunkan rata-rata keragaman genetik dalam populasi.

Variasi 7 alel yang dihasilkan pada lokus AY295 (alel A, B, C, D, E, F dan G) memiliki empat alel spesifik yakni pada alel D, E, F dan G yang hanya dimiliki oleh itik Bayang yang berasal dari
Kecamatan Bayang dan tidak dimiliki itik Bayang dari Kecamatan Lengayang. Alel spesifik tersebut dapat dijadikan sebagai penciri khas itik Bayang dari Kecamatan Bayang. Alel yang dihasilkan pada lokus AY295 bersifat polimorfik sebesar 70,83\% dan bersifat monomorfik sebesar $29,17 \%$.

Perbedaan ukuran alel antara itik Bayang dengan itik lokal Cina diduga karena terjadinya penambahan (insersi), pengurangan (delesi) dan perubahan pada jumlah copy DNA runutan DNA yang berulang (Sumantri et. al., 2007).

Jenis alel, ukuran alel, frekuensi alel, genotype dan frekuensi genotipe itik Bayang dapat dilihat pada Tabel 2. Frekuensi alel itik Bayang adalah frekuensi relatif dari jumlah itik Bayang terhadap jumlah total alel itik Bayang yang terdapat dalam populasi. 
Tabel 2. Jenis dan ukuran alel pada itik Bayang menggunakan 2 lokus mikrosatelit.

\begin{tabular}{|c|c|c|c|c|c|c|}
\hline Lokus & $\begin{array}{c}\text { Jumlah } \\
\text { Alel }\end{array}$ & $\begin{array}{c}\text { Populasi } \\
\text { Sampel }\end{array}$ & Genotip (n) & $\begin{array}{l}\text { Frekuensi } \\
\text { Genotip } \\
(\%)\end{array}$ & $\begin{array}{l}\text { Alel dan } \\
\text { Ukuran } \\
\text { (bp) }\end{array}$ & $\begin{array}{c}\text { Frekuensi } \\
\text { Alel (\%) }\end{array}$ \\
\hline \multirow{2}{*}{ CMO211 } & 2 & 24 & AA (18) & 75 & A (150) & 87,50 \\
\hline & & & $\mathrm{AB}(6)$ & 25 & $\mathrm{~B}(200)$ & 12,50 \\
\hline \multirow[t]{11}{*}{ AY295 } & 7 & 24 & $\mathrm{AC} \mathrm{(4)}$ & 16,67 & A (214) & 16 \\
\hline & & & $\mathrm{BCF}$ (1) & 4,17 & B (245) & 24 \\
\hline & & & $\mathrm{DD}(1)$ & 4,17 & C (273) & 16 \\
\hline & & & $\mathrm{BD}(1)$ & 4,17 & $\mathrm{D}(300)$ & 16 \\
\hline & & & $\mathrm{DE}(1)$ & 4,17 & E (324) & 12 \\
\hline & & & CEFG (1) & 4,17 & $\mathrm{~F}(359)$ & 12 \\
\hline & & & $\mathrm{EF}(1)$ & 4,17 & G (454) & 4 \\
\hline & & & BB (5) & 20,83 & & \\
\hline & & & $\mathrm{AA}(1)$ & 4,17 & & \\
\hline & & & $\mathrm{AB}(5)$ & 20,83 & & \\
\hline & & & $\mathrm{BC}(3)$ & 12,5 & & \\
\hline
\end{tabular}

Hasil amplifikasi menunjukkan bahwa jumlah alel itik Bayang yang dihasilkan pada lokus CMO211 dan AY295 beragam. Keragaman alel dari 24 sampel itik Bayang pada lokus CMO211 adalah 25\% dan lokus AY295 adalah 70,83\%. Hasil penelitian ini menunjukkan bahwa lokus CMO211 dan lokus AY295 bersifat polimorfik.

Penentuan nilai heterozigositas itik Bayang hasil amplifikasi pada lokus CMO211 dan AY295 yakni dengan penentuan jumlah alel yang dihasilkan. Jika terdapat dua alel atau lebih maka disebut heterozigot, sedangkan jika hanya terdapat satu alel, maka disebut homozigot. Perbedaan keragaman alel hasil penelitian disebabkan karena perbedaan ukuran DNA mikrosatelit pada masing-masing lokus (Moxon et. al., 1999). Nei dan Kumar (2000) menyatakan bahwa variasi genetik terjadi jika terdapat dua alel atau lebih dalam satu populasi dan biasanya lebih dari $1 \%$.

Variasi alel itik Bayang pada lokus CMO211 dan AY295 ditemukan alel spesifik, yakni alel B pada lokus CMO211 dan alel D, E, F dan G pada lokus AY295. Alel B pada lokus CMO211 dan alel D, E, F dan G pada lokus AY295 hanya ditemukan pada itik Bayang yang berasal dari Kecamatan Bayang.

Berdasarkan jumlah dan macam alel yang dihasilkan dari lokus CMO211 dan AY295 menunjukkan kedua lokus memiliki tingkat keragaman yang berbeda. Semakin besar jumlah alel yang teramplifikasi dari suatu lokus, maka semakin tinggi keragaman lokus tersebut. Keragaman lokus AY295 lebih tinggi dari lokus CMO211, karena lokus AY295 dapat mengamplifikasi 7 macam alel, yakni alel 
A, B, C, D, E, F dan G, sedangkan lokus CMO211 hanya dapat mengamplifikasi 2 macam alel, yaitu alel A dan B.

\section{KESIMPULAN}

Marka mikrosatlite itik Bayang pada lokus CMO211 dan AY295 bersifat polimorfik. Lokus CMO211 menghasilkan dua macam alel, yaitu alel A dan alel B dengan panjang alel $150-200$ bp. Lokus AY295 menghasilkan 7 alel, yaitu alel A, B, C, D, E, F dan $\mathrm{G}$ dengan panjang alel 214 - 454 bp. Pada Lokus CMO211 frekuensi alel tertinggi adalah alel A sebesar $87,5 \%$ dan alel B sebesar 12,5\%, sedangkan pada lokus AY295 frekuensi alel berturut-turut adalah alel B (24\%), alel A (16\%), alel C (16\%), alel D (16\%), alel E (12\%), alel F (12\%) dan alel G (4\%).

\section{SARAN}

Perlu dilakukan penelitian lanjutan untuk menentukan keragaman itik Bayang dengan jumlah sampel dan lokus yang lebih banyak, sehingga hasil yang diperoleh akan lebih akurat. Selain itu, identifikasi keragaman itik Lokal Bayang dapat dilakukan dengan penciri DNA lainnya seperti dengan menggunakan teknik PCR-RFLP, dan PCR-SSCP.

\section{UCAPAN TERIMAKASIH}

Ucapan terimakasih disampaikan kepada DP2M Ditjen Pendidikan Tinggi atas bantuan biaya penelitian dalam Skim
Hibah Strategis Nasional pada Tahun 2010 dengan judul penelitian "Inventarisasi, Karakterisasi dan Konservasi Sumber Daya Genetik Itik Lokal Sumatera Barat".

\section{DAFTAR PUSTAKA}

Bennet, P. 2000. Microsatellites. J. Clin. Pathol. 53:177-183.

Ciampolini, R., K. M. Goudarzi., D. Vaiman., C. Dilman, E. Mazzanti, J. L. Fouley, H. Leveziel and D. Cianci. 1995. Individual multilocus genotypes using microsatellites polymorphism to permit the analysis of the genetic variability within and between Italian beef cattle. J. Anim. Sci. 73: 3259-3268.

Clementino, C.S., F.J.V. Barbosa., A.M.F. Calvalo., R.A.R. Costa-Filho, G.R. Silva., E.G. Campelo., F.B. Britto and F.M. Diniz. 2010. Microsatelite DNA loci for population studies in Brazilian chicken ecotypes. Internat. J. Poult. Sci. 9 (12): 100-106.

Clisson, I., M. Lathuilliere and B. CroauRoy. 2000. Conservation and evolution microsatellite loci in primate taxa. Am. J. Prim. 50: 205214.

Edwards, C.J., C. Gailard., D. G. Bradley and D. E. Machugh. 2000. Y-spesific microsatellite polymorphism in a 
range of bovine species. Anim. Genet. 31: 127-130.

Ismoyowati and D. Purwantini. 2009. An estimation of genetic variation of Indonesian Local duck using microsatellite marker. Asian J. Poult. Sci. 4 (4): 198-204.

Kusnadi, E and F. Rahim. 2009. Effect of floor density and feeding system on the weights of bursa of fabricius and spleen as well as the plasma triiodothyronine level of Bayang duck. Pakistan J. Nutrition. 8 (11): 1743-1746.

Moxon, E. R and C. Wills. 1999. DNA Microsatellite: Agents of Evaluation. Scientific American, USA.

Muladno,. R. R. Noor and B. Tappa. 2000. The genomic mapping of Bali cattle: Early strategy and an effort to production of "tandemly repeated sequence" and "interspearse repetitive sequence" as DNA marker. Report of Integrated Competitive Research Grand Program VI (19971999). National Research Council, Ministry of Research and Technology.

Nei, M. 1987. Molecular Evolutionary Genetics. Columbia University Press. New York.
Nei, M. and S. Kumar. 2000. Molecular Evolutionary and Phylogenetics. Oxford University Press, New York.

Rusfidra, M. H. Abbas dan R. Yalti. 2012. Struktur populasi, ukuran populasi efektif dan laju inbreeding per generasi itik Bayang. Prosiding Seminar Nasional Peternakan Berkelanjutan IV. Bandung: Fakultas Peternakan Universitas Padjajaran. ISBN: 978-602-95808-6-2.

Rusfidra dan Y. Heryandi, 2010. Inventarisasi, karakterisasi dan konservasi sumber daya genetik itik Lokal Sumatera Barat. Laporan Penelitian Hibah Strategis Nasional Tahun 2010 .

Sambroook, J., E. Fritsch and T. Maniatis. 1989. Molecular Cloning; Laboratory Manual. $2^{\text {nd }}$ Edition. Cold Spring Harbor Laboratory Press.

Silva, F., L. Gusmao and A. Amorim. 1999. Segregation analysis of tetra and penta nucleotide short tandem repeat polymorphism: Deviation from mendelian expectation. Electrophoresis, 20: 1697-1701.

Su, Y., R. Long., G. Chen., X. Wu., K. Xie and J. Wan. 2007. Genetic analysis of six endangered local duck population in China based on microsatellite marker. J. Genetics and Genomics. 
Sumantri, C., A. Angraini., A. Farajalah dan D. Perwitasari. 2007. Keragaman mikrosatelit DNA sapi perah Frisien Holstein di Balai Pembibitan Ternak Unggul Batu Raden. Laporan Penelitian. Fakultas Peternakan IPB Bogor.
Tixier-Boichard, M, A. Bordas and X. Rognon. 2009. Characterisation and monitoring of poultry genetic resources. World's Poult. Sci. 65: 272-285. 